\begin{tabular}{|c|c|c|c|c|c|c|}
\hline \multirow{4}{*}{ Impact Factor: } & ISRA (India) & $=3.117$ & SIS (USA) & $=0.912$ & ICV (Poland) & $=6.630$ \\
\hline & ISI (Dubai, UAE & $=0.829$ & РИНЦ (Russia & $=0.156$ & PIF (India) & $=1.940$ \\
\hline & GIF (Australia) & $=0.564$ & ESJI (KZ) & $=8.716$ & IBI (India) & $=4.260$ \\
\hline & JIF & $=1.500$ & SJIF (Morocco & $=5.667$ & OAJI (USA) & $=0.350$ \\
\hline
\end{tabular}

\begin{tabular}{|c|c|}
\hline $\begin{array}{l}\text { SOI: } \underline{1.1 / \mathrm{TA}} \\
\text { International Sc } \\
\text { Theoretical } \mathbf{\&} \mathbf{A}\end{array}$ & $\begin{array}{l}S \text { DOI: } 10.15863 / T A S \\
\text { ientific Journal } \\
\text { pplied Science }\end{array}$ \\
\hline p-ISSN: 2308-4944 (print) & e-ISSN: 2409-0085 (online) \\
\hline Year: $2019 \quad$ Issue: 05 & Volume: 73 \\
\hline Published: 16.05 .2019 & http://T-Science.org \\
\hline
\end{tabular}

QR - Issue

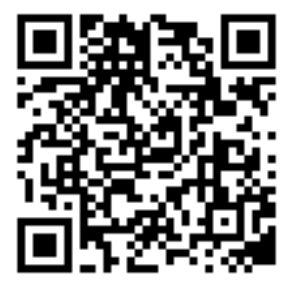

QR - Article

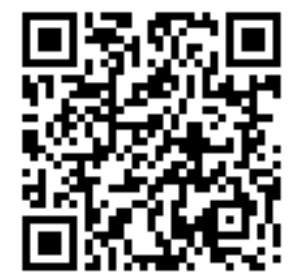

Kamolitdin Sadriddinovich Sultonov

Doctor of Agricultural Sciences,

Department of Fruit Growing and Viticulture,

Tashkent State Agrarian University,

Tashkent, Uzbekistan

Shamshoda Farhod qizi Eraliyeva

Third Course Bachelor Student,

Faculty of Fruit Growing and Viticulture

Tashkent State Agrarian University,

Tashkent, Uzbekistan

\title{
INTENSIVE REPRODUCTION OF GRAPEVINE SEEDLINGS BY VERTICAL AND HORIZONTAL LAYERING METHOD
}

Abstract: The article outlines survey results conducted on implementation of intensive reproduction of grapevine seedlings through horizontal and vertical layering methods. For this, mother bushes of grapevine are layered vertically and horizontally, and at the end of vegetation the rooted new plants are separated from the parent bush. Experiment results showed the preferences of horizontal layering method on seedling production per area unit. Hereby, the production of seedling per ha made 123138 pieces.

Key words: grapevine, layering, horizontal, vertical, mother bush, seedling, root, scion, node, digging, variety. Language: English

Citation: Sultonov, K. S., \& Eraliyeva, S. F. (2019). Intensive reproduction of grapevine seedlings by vertical and horizontal layering method. ISJ Theoretical \& Applied Science, 05 (73), 68-70.

Soi: http://s-o-i.org/1.1/TAS-05-73-13 Doi: crossef https://dx.doi.org/10.15863/TAS.2019.05.73.13

\section{Introduction}

In recent years greater attention is paid to further broadening of intensive gardens and vinery areas in the republic. Improvement of vinery areas and seedling production system is particularly mentioned in Actions strategy on further development of the Republic of Uzbekistan [1]. Enlargement of vinery areas requires in its turn the abundant provision of high quality grapevine seedling annually.

Production of seedlings by layering and rooting hardwood and green scion is a widespread way of vegetative reproduction of grape seedlings in viticulture.

Some varieties with cuttings of low rooting capacity can be propagated in brooks, furrows and by ordinary layering.

\section{Materials and methods}

The researches and experiments on reproduction of grapevine seedlings by layering method have been conducted according to the methods recommended by Kh.Ch.Buriyeva et. al [2] and M.I.Markin [4] and A.Zarmaev [6]. At the end of vegetation the seedlings were evaluated as per standard [3]. As an object of research was used black Kishmish variety which was registered in state registration [5].

In order to get highest quality grapevine seedlings by vertical layering the one -year old all shoots are cut remaining 3-4 bud nodes of mother bushes at the end of the second vegetation and the beginning of next year (February). When new shoots grown out of these buds reach to 15-20 sm (May), they are covered with the soil of vinery rows by leaving 2-3 top leaves and 2 tops leaves are half-cut. After the shoots grow $10-15 \mathrm{~cm}$, abovementioned technological measure is conducted again.

In vegetation period the accumulated soil is kept wet. In autumn of the current year or in spring of next year the accumulated soil is opened and layer seedlings with well-developed roots are separated from parent plant with vine-scissors. The seedlings reproduced by layering are also used to create nurseries for cuttings and industrial vineries. For getting high quality seedlings by horizontal layering the brooks are dug with depth 20-25 $\mathrm{cm}$ in rows around mother bushes. The shoots inside the 


\begin{tabular}{|c|c|c|c|c|c|c|}
\hline \multirow{4}{*}{ Impact Factor: } & ISRA (India) & $=3.117$ & SIS (USA) & $=0.912$ & ICV (Poland) & $=6.630$ \\
\hline & ISI (Dubai, UAE & $=0.829$ & РИНЦ (Russia & $=0.156$ & PIF (India) & $=1.940$ \\
\hline & GIF (Australia) & $=0.564$ & ESJI (KZ) & $=8.716$ & IBI (India) & $=4.260$ \\
\hline & JIF & $=1.500$ & SJIF (Morocce & $=5.667$ & OAJI (USA) & $=0.350$ \\
\hline
\end{tabular}

bush are lied into these brooks and covered with soil in such way that developed shoots in each node are remained uncovered (Picture).

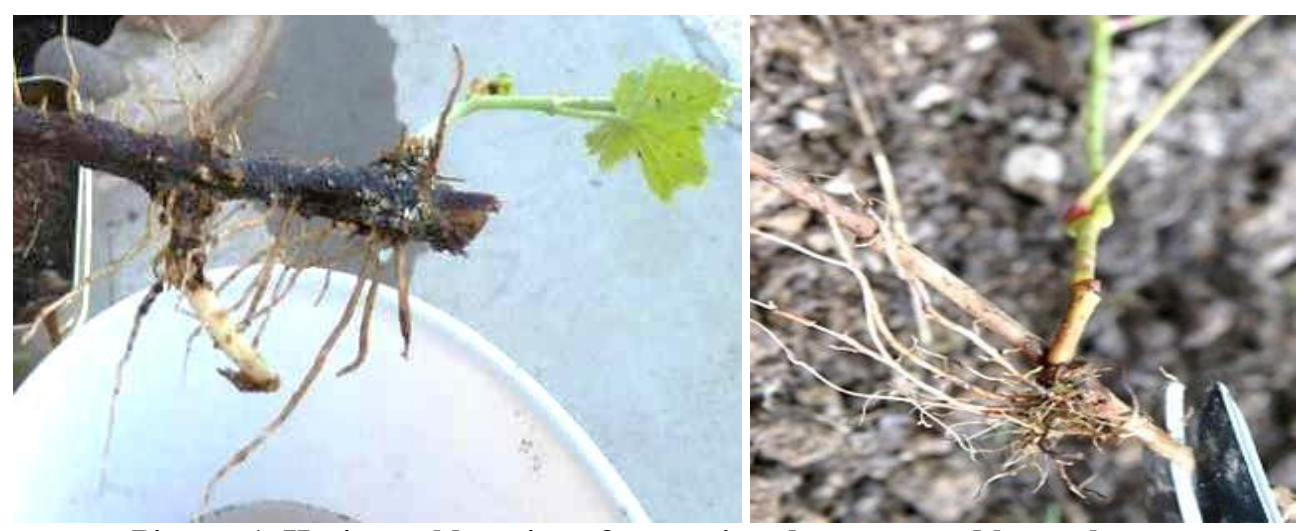

Picture 1. Horizontal layering of grapevine shoots: rooted layer shoots.

The roots are formed in each node of shoots covered with soil and shoots are formed in each bud. In autumn this shoot is uncovered not destroying its root system and each node is separated into parts in such way that each of them should define a standard seedling.

\section{Results and discussion}

Our researches conducted on the study of impact of cultivation conditions and methods of clone mother bushes of black Kishmish variety of grapevine on the production and quality of layer seedlings have enabled us to determine the preference of growing plants in protected area condition. Therefore, when the seedlings of black Kishmish grape variety have been propagated in protected area condition by vertical and horizontal layering, layer plants have grown well under vertical layering method.

The length of shoots of seedlings cultivated by this method reached to $69,9 \mathrm{~cm}$ at the end of vegetation (November) and each plant could form average 12 leaves. While in seedlings propagated by horizontal layering these indicators showed $54,4 \mathrm{~cm}$ and 10 leaves relatively. The difference of seedlings in development consisted $12,2-16,7 \%$ with the preference of vertical layering.

Almost this kind of difference is observed in growing of plant roots reproducted by these both methods. It was observed that in each mother bush four roots of first order with $26 \mathrm{~cm}$ was formed in vertical layering of plant propagation and eight roots of second order with $15 \mathrm{~cm}$. In grapevine seedlings propagated by horizontal layering these indicators made 7 pieces and $13 \mathrm{~cm}$ relatively. According to total weight of developed root system of plants vertically layered seedlings have $9,5 \%$ more preferences compared to horizontally layered seedlings.

Biological factor of maturation level of the shoots which are important to maintain plant life during autumn-winter periods has showed the same high level 93,2-95,3\% in both cultivation methods. In both methods the maturation level of shoots of seedlings had similar indicators (table).

Table 1. The impact of cultivation conditions and methods of grape layers on seedling production from two-year old mother bushes

\begin{tabular}{|l|l|l|l|l|l|}
\hline \multirow{2}{*}{ Biometrical parameters } & \multicolumn{2}{|l|}{ Protected area } & \multicolumn{2}{l|}{ Open space } & \multirow{2}{*}{$S x_{05}$} \\
\cline { 2 - 5 } & $\begin{array}{l}\text { Vertical } \\
\text { layer }\end{array}$ & $\begin{array}{l}\text { Horizontal } \\
\text { layer }\end{array}$ & $\begin{array}{l}\text { Vertical } \\
\text { layer }\end{array}$ & $\begin{array}{l}\text { Horizontal } \\
\text { layer }\end{array}$ & \\
\hline Shoot growth, date & 20.12 .15 & 24.12 .15 & 30.05 .14 & 7.06 .14 & - \\
\hline The length of central shoot, cm & 69,9 & 54,4 & 39,5 & 32,7 & 3,2 \\
\hline Leaves quantity, pieces & 12,0 & 10,0 & 8,0 & 6,0 & 1,3 \\
\hline I order roots quantity, pieces & 4,0 & 3,0 & 3,0 & 3,0 & 0,5 \\
\hline II order roots quantity, pieces & 8,0 & 7,0 & 5,0 & 5,0 & 0,4 \\
\hline I order roots length, cm & 26,0 & 23,0 & 22,0 & 21,0 & 0,6 \\
\hline II order roots length, cm & 15,0 & 13,0 & 13,0 & 11,0 & 0,8 \\
\hline Total weight of roots, gr. & 99,7 & 90,3 & 75,7 & 75,5 & 1,1 \\
\hline
\end{tabular}




\begin{tabular}{|c|c|c|c|c|c|c|}
\hline \multirow{4}{*}{ Impact Factor: } & ISRA (India) & $=3.117$ & SIS (USA) & $=0.912$ & ICV (Poland) & $=6.630$ \\
\hline & ISI (Dubai, UAE & $=0.829$ & РИНЦ (Russia & $=0.156$ & PIF (India) & $=1.940$ \\
\hline & GIF (Australia) & $=0.564$ & ESJI (KZ) & $=8.716$ & IBI (India) & $=4.260$ \\
\hline & JIF & $=1.500$ & SJIF (Morocce & $=5.667$ & OAJI (USA) & $=0.350$ \\
\hline
\end{tabular}

\begin{tabular}{|l|l|l|l|l|l|}
\hline Maturation level of shoots, \% & 95,3 & 93,2 & 87,8 & 86,3 & 1,7 \\
\hline Diameter of root top, mm & 8,0 & 7,0 & 7,0 & 7,0 & 0,4 \\
\hline Seedling production, pcs/ha & 153320 & 199980 & 134234 & 149440 & 1297 \\
\hline Standard seedling production, \% & 87,3 & 85,5 & 85,7 & 82,4 & - \\
\hline Standard seedling production, pcs/ha & 133848 & 169983 & 115038 & 123138 & 839 \\
\hline
\end{tabular}

Comments: - mother bushes cut in 20.02.2016;

- planting scheme of mother bushes 1,5x1,0 m.;

- the date of created nurseries in protected area-20.11.2014;

- the date of created nurseries in open areas - 10.04.2014;

- the quantity of mother bushes per ha-6666 pcs.

The analysis of development of black Kishmish grapevine variety layers cultivated by the abovementioned methods in an open area condition has indicated that there is no difference between the development of ground surface part and root system of plant. Apparently, considering farm opportunities both layering methods can be applied successfully in grapevine seedling reproduction and these seedlings which are produced by these methods can be used in creating industrial nurseries.

If seedling production methods are compared to each other by the conditions (protected area, open area), then the plants cultivated in protected area have distinct preference. The reason is longer vegetation period in which sunlight energy is used continuously, provision of constant mean daily and monthly air temperature and favourable soil moisture in annual development.

When black Kishmish grape variety has been propagated by two methods, layer development in protected area has been $15-20 \%$ higher than in open area.

If we compare two propagation ways by the production of common and standard seedlings in useful fields of protected and open areas, then it is observed that seedling propagation by horizontal layering has an advantage.

\section{Conclusion}

This type of seedling propagation allowed to produce 199980 pieces of rooted layer seedlings per ha of nurseries. And the cultivation of seedlings by this way in open area led to obtain 149440 pieces of standard seedlings. Under vertical layering method in both conditions 123138 and 153320 pieces of rooted layer seedling are produced.

The production of qualitative clone grapevine seedlings by this recommended method allowed to achieve standard seedling production of black Kishmish variety 1,9-2,7 times more than the production of seedlings from hardwood cuttings which is generally accepted in the republic and in protected area their quantity makes 133,8-169,9 thousand per ha, while in open area 115,0-133,1 thousand pieces.

\section{References:}

1. Mirziyoyev, S. (2017, February 7). PD-4947. About Actions strategy on further development of the republic of Uzbekistan. President decree. Tashkent.

2. Buriyev, K. C., et al. (2014). The methodics of accounts and phenological observations for conducting experiments on fruit and berry plants. (p.64). Tashkent.

3. (2009). Uzbekistan State Standard 1191-2009 (1191-2009). Grapevine seedlings and cuttings. General technical terms. (p.12). Tashkent.

4. Markin, M. I. (1951). Intensive grapevine propagation methods. (pp.22-31).
Methodological instruction - Simpheropol, Krimizdat.

5. (2015). State registration for agricultural crops recommended for sowing in the Republic of Uzbekistan. (p.61). Tashkent.

6. Zarmaev, A. A. (2004). Strategy for the production of planting material of grapes in the Chechen Republic. (pp.16-23). Krasnodar.

7. Kravchenko, L.V., \& Doroshenko, N. P. (2005). Innovative processes in the nursery of grapes. Winemaking and viticulture, Moscow, №5. pp. 12-14. 